\title{
A FREEZE-FRACTURE STUDY ON THE DEVELOPING SATELLITE CELLS OF SPINAL GANGLIA IN THE CHICK EMBRYO
}

\author{
CLAUDIO A. FERRAZ DE CARVALHO - CIRO F. DA SILVA * *
}

\begin{abstract}
SUMMARY - A freeze-fracture analysis of the satellite cells of spinal ganglia of the chick embryo was performed in 8 successive stages of development, from the 5th incubation day to hatching. The characteristic laminar disposition of the cells were first observed on the 7 th day. Tight junctions were found at the 20 th incubation day. Small groups or irregular aggregates of particles, but not gap junctions, were described on the 7 th and 8 th days. Pinocytotic vesicles were pointed out in the different stages considered.
\end{abstract}

Estudo com a técnica da crio-fratura das células satélltes dos gánglios sensitivos do embriào de galinha.

RESUMO - Foi feita análise pelo método da crio-fratura de células satélites em 8 diferentes fases do desenvolvimento do embriāo de galinha, do quinto dia à eclosāo. A disposição laminar característica das células foi observada inicialmente no sétimo dia. Foram encontradas junçōes do tipo «tight» no $20^{\circ}$ dia de incubação. Pequenos grupos ou agregados de partículas foram descritos no sétimo e oitavo dias, mas não típicas junçōes «gap». Vesículas de pinocitose foram apontadas nos diferentes estágios considerados.

The satellite cells of the sympathetic and sensory ganglia have been extensively studied (see Pannese 7, for a review). Pannese et al.5,6 using the freeze-fracture technique, analysed the developing satellite cells in the spinal ganglia of chick embryos, considering particularly the intercellular junctions and other membrane specializations.

In the present paper, we study with the same technique the satellite cell membranes of the lumbar sensory ganglia of the chick embryo in 8 stages of development, from the 5 th to the 20 th incubation days.

\section{MATERIAL AND METHODS}

Fragments of lumbar sensory ganglia of chick embryos at the 5th, 7th, 8th, 10th, 14th, 16th, 18th and 20th days of incubation (three) specimens for each age) were removed and fixed in $2 \%$ glutaraldehyde in $0.1 \mathrm{M}$ sodium cacodylate buffer ( $\mathrm{pH} 7.2,480 \mathrm{mOs}$ ) at $4 \circ \mathrm{C}$ for $2 \mathrm{hr}$, frozen in liquid nitrogen-Freon 22, freeze-fractured (in a Balzers BAF 301 unit) and coated with carbon-platinum. The replicas were cleaned in $2.5 \%$ sodium hypochlorite and examined in a Phillips EM-201 electron microscope of the Heart Institute of the são Paulo Medical School.

This work was performed in the Department of Anatomy, Institute of Biomedical Science, University of Săo Paulo (* Full Professor, ** Assistant Professor) and supported by a grant from FAPESP (PB-86/3336-0) to C.A.F.C. We thank Prof. Antonio Sesso for the preparation of the freeze-fracture replicas. 

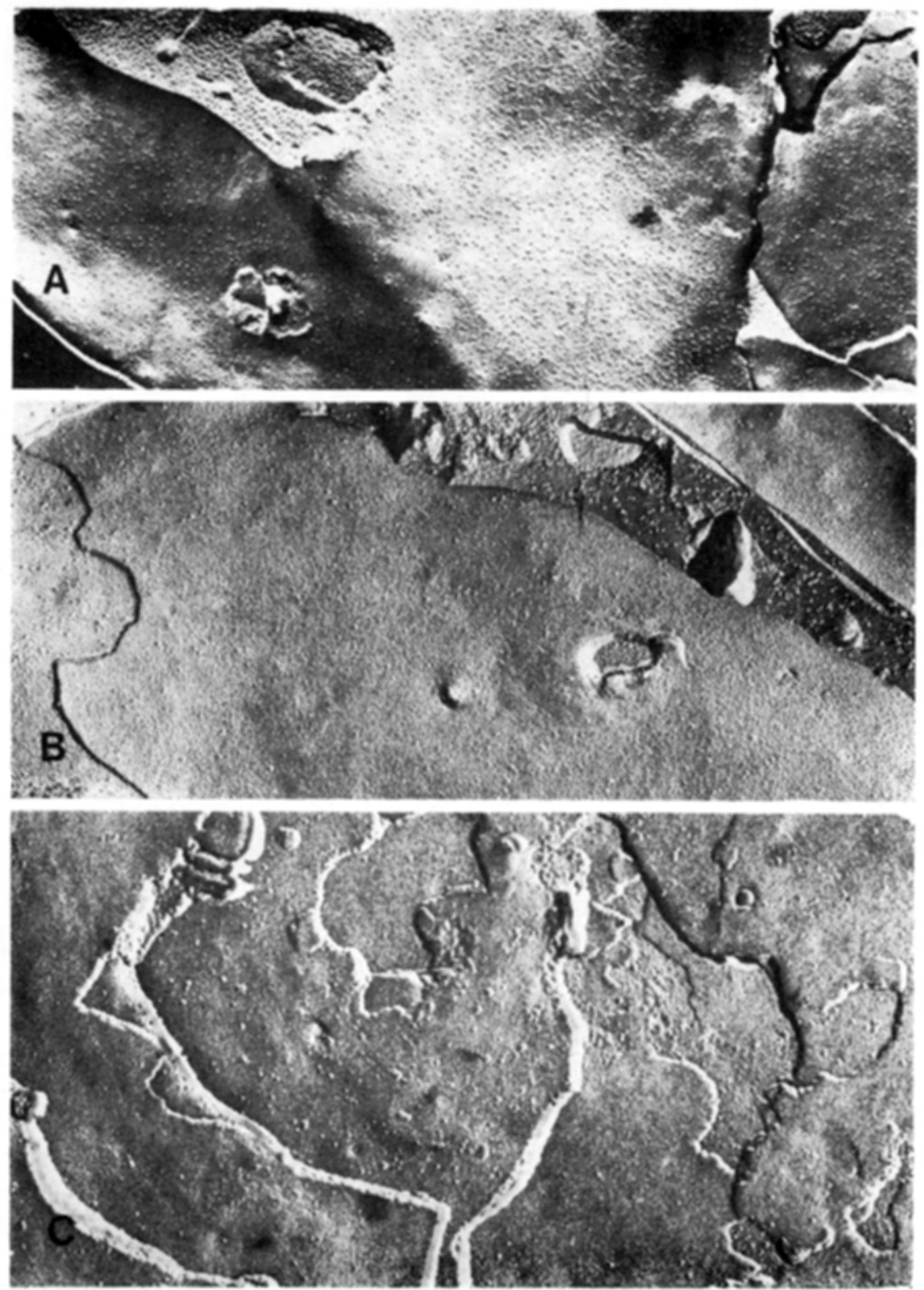

Fig. 1 - Freeze-fnacture replicas of spinal ganglion satellite cells of chick embryos. $A$, 5th incubation day $(\times 21300) ; B, 7$ th incubation day $(\times 45000) ; C, 14 t h$ incubation day $(\times 45000)$, 

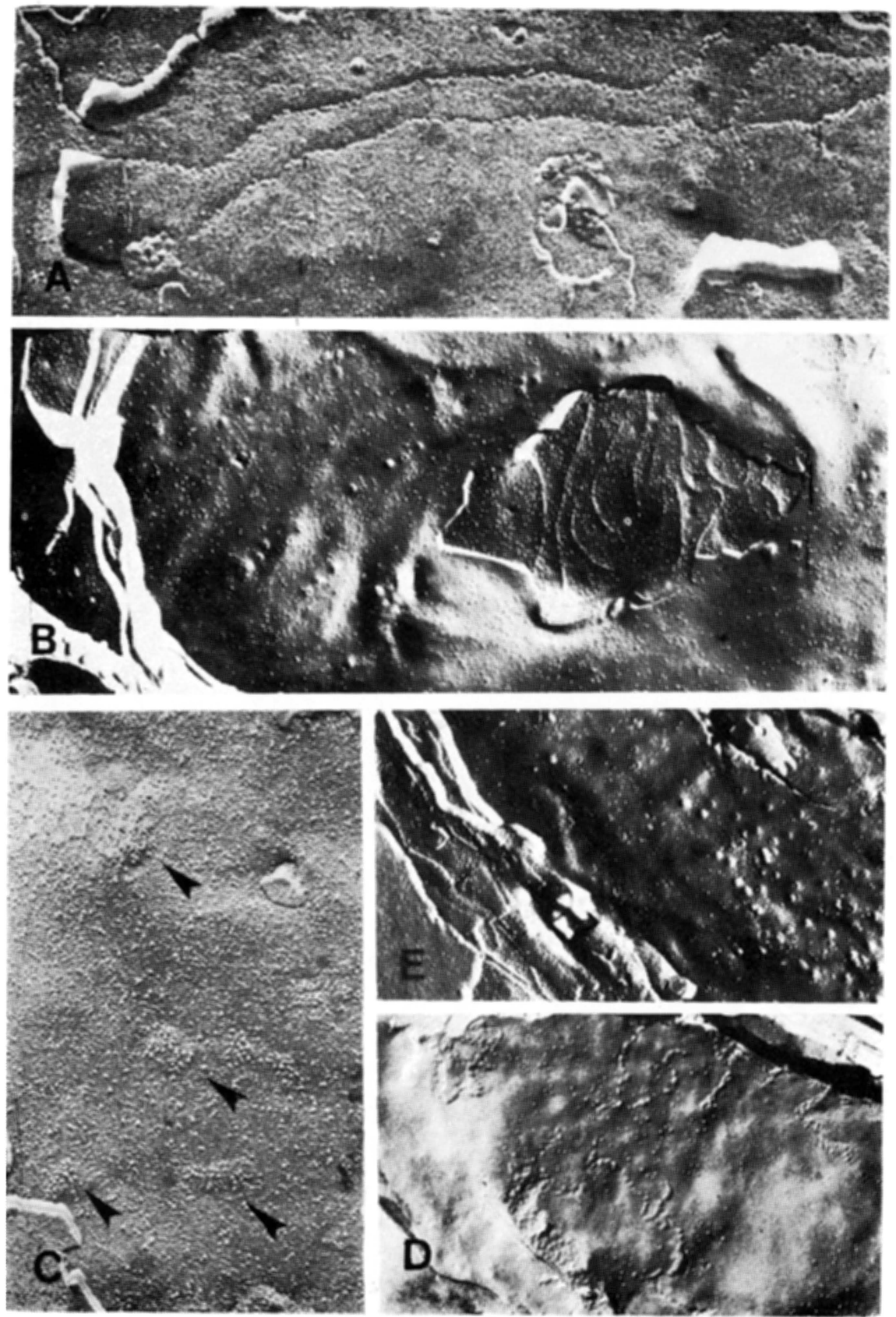

Fig. 2 - Freeze-fracture replicas of spinal ganglion satellite cells of chick embryos. $A$, 14th incubation day ( 45000$) ; B$, 20th incubation day $(\times 21300) ; C$, 7th incubation day (arrow $=$ particle aggregates) $(\times 45000) ; D$, sth incubation day ( $\times 21300) ; E$, Yth incubation day ( $\times 45000)$. 


\section{IRESULTS}

Despite its apparent complexity the satellite cell surface was relatively smooth. At the 5th incubation day the undifferentiated cells were intermingled with neuroblasts, showing irregular shape (Fig. 1A). At the 7 th incubation day the satellite cells acquired the characteristic flattened shape around the neuroblast (Fig. 1B). Extensive laminar expansions could be seen, forming a system of interdigitating processes already on the 8th day (Fig. 1C) and becoming more complex in later developmental stages. Tight-like junctions could be observed at the 10th and 14th incubation days (Fig. 2A). They were relatively isolated, describing slightly irregular trajectories and forming grooves on the $E$ face whose botton sometimes showed a single row of particles. Typical tight junctions were frequently seen close to hatching (Fig. 2B). They seemed to be present mainly between the laminar processes of the satelite cells. Particle islets (gap-like junctions) (Fig. 2C) were observed at the 7th incubation day, although they were more characteristic at the 8th day (Fig. 2D). In other stages studied, gap or gap-like junctions were not apparent.

Pinocytotic-like vesicles were seen in variable amount in all embryonic stages, being more numerous and concentrated in certain areas, probably near to the neuroblasts or nerve cells (Fig. 2E).

\section{COMMENTS}

Typical tight junctions between satellite cells similar to those we found on the 26th incubation day are not refered by Pannese et al.5,6. However, they mention the presence of short strands, which appeared as ridges about $15 \mathrm{~nm}$ thick on the $P$ face and as thinner grooves on the $\mathrm{E}$ face, isolated or grouped under various angles, which could correspond to the structures we described as tight-like junctions at the 14th day. Revel et al.9 and Decker and Friend 3 interpreted those ridges as remnants of well developed tight junctions. Typical tight junctions did not exist in our material before the 20th embryonic day. More than remnants or rudiments, these tight-like junctions 5 could represent developing tight junctions, since they were seen in our material only at the 10th and 14th days, while typical tight junctions were found only on the 20th day. Similar strands (grooves on the $E$ face, according to Pannese 5) probably link mechanically adjacent satellite cells and persist even in the adult fowl.

Typical gap junctions were not observed in the present study. Only small groups or irregular aggregates of particles which we named gap-like junctions were found at the 7 th and 8 th days. Pannese 5 observed these structures very seldom and interpreted them as a result of technical failure.

Whether such structures assume the functional role of real gap junctions it could not be decided here. Gap junctions allow ions and small molecules to pass from one cell to another $1,2,8$ and might have a particular role during development 4.

\section{REFERENCES}

1. Bennet MVL, Trinkaus JP - Electrical coupling between embryonic cells by way of extracellular space and specialized junctions. $J$ Cell Biol 44:592, 1970.

2. Brightman M, Reese TS - Junctions between intimately apposed cell membranes in the vertebrate brain. J Cell Biol 40:648, 1969.

3. Decker RS, Friend DS - Assembly of gap junctions during amphibian neurulation. $J$ Cell Biol 62:32, 1974.

4. Pannese $\mathbf{E}$ - The histogenesis of the spinal ganglia. Adv Anat Embryol Cell Biol 47:6, 1974.

5. Pannese E, Luciano L, Iurato $\mathbf{S}$, Reale $\mathbf{E}$ - Interceliular junctions and other membrane specializations in developing spinal ganglia: a freeze-fracture study. J Ultrastruct Res 60:169, 1977.

6. Pannese E, Luciano L, Reale L - Intercellular junctions in developing spinal ganglia. Zoon 6:129, 1978.

7. Pannese E - The satellite cells of the sensory ganglia. Adv Anat Embryol Cell Biol $65: 1,1981$.

8. Revel JP, Karnovsky MJ - Hexagonal array of subunits in intercellular junctions of the mouse heart and liver. J Cell Biol 33:7, 1967.

9. Revel JP. Yip P. Chang LL - Cell junctions in the early chick embryo: a freeze-etch study. Dev Biol 35:302, 1973. 